Article

\title{
Ostalgia in Czech Films about Normalisation Created Post-1989
}

\author{
Luboš Ptáček
}

Department of Theatre and Film Studies, Faculty of Arts, Palacký University, Křížkovského 10, 77200 Olomouc, Czech Republic; lubos.ptacek@upol.cz

Received: 31 August 2018; Accepted: 31 October 2018; Published: 14 November 2018

\begin{abstract}
This piece will introduce Czech ostalgic films set in the normalisation period (1969-1989) and will interpret the basic divide between nostalgic representation of the period and the openly anti-communist stances of the films' creators. The methodological frame of this research comes from Robert Rosenstone's approach of representation of history in film. To interpret ostalgia in Czech film, I use ideas from Daphne Berdhal and Svetlana Boym. I described the nostalgic elements and their functions in the structure of the films, taking into account their story, characters, settings, film style, narration, genre, and audience response (identification, causality of emotional experience). Czech ostalgic films about the normalisation period are interpretively ambivalent. The interpretational tension appears out of a fundamental divide between a clear refusal of communism and an idyllic view of the socialist past. They cannot be simply classified into restorative or reflective nostalgia. The younger generation of spectators perceives ostalgic films in the mode of reflective nostalgia; on the other hand, the older generation perceive the films in terms of restorative nostalgia. A different way of perceiving ostalgia reveals a misunderstanding between generations of the current Czech society. Due to singular anti-communist viewpoints and emphasised liberal values, the films cannot be interpreted in a desire for an idealised home in a communist past, but as a desire for a present home and its security, which cannot be clearly conceptualised. The concept of reflective nostalgia can be linked with the theory of Berdhal. The films cannot be perceived as a desire for an idealised home in a communist past due to specific anti-communist viewpoints and highlighted liberal values, but as a need for a home and security that cannot be directly conceptualised. This appearance of reflective nostalgia can be connected with the theory stated by Berdhal.
\end{abstract}

Keywords: nostalgia; ostalgia; Czech film; Czech history; normalisation; post-communism

\section{Introduction}

This text introduces a summary of a side topic in my research of Czech historical film post-1989, which I worked on in 2014-2018 (Ptáček 2018). In the frame of this research, all films shot about normalisation were analysed. Here, I will focus on films with overarching ostalgic elements. The scope of this article does not allow the introduction of complex film analysis; thus, I will concentrate on a summary of results from film analysis and their interpretation in the context of ostalgic art and film. The conclusion should result in an explanation of how the meaning of ostalgia is identic, and how it differs from the interpretations of Daphne Berdhal and Svetlana Boym. The methodological frame of this research comes from Robert Rosenstone's approach to representation of history in film, as formulated in the books Visions of the Past: The Challenge of Film to Our Idea of History (Rosenstone 1995) and History on Film/Film on History (Rosenstone 2012).

Like Rosenstone with his analysis of films about the Holocaust, I ask: How can a group of (in my case ostalgic) films show a greater perspective of historical themes? How can these films relate to a greater historical discourse? How do historical films present current issues? In the first 
section is introduced the tradition of Czech nostalgic films from the 1930s to the 1980s and its various ideological functions. In the second section, the findings of the analysis of nostalgic elements in films about normalisation on the level of character motifs, narration, genre, and audience response are summarised. The third section describes valued ideological judgments in relation to history and the contemporary, which mainly represents the behaviour and actions of characters, the interactions between characters, and arises from the narrative or is presented by a film narrator. In the last section, the audience response is interpreted as a stance towards ostalgic films through their experience with post-communism.

To analyse ostalgia in Czech film, I use ideas from German sociologist Daphne Berdhal, mainly from her book On the Social Life of Postsocialism: Memory, Comsupsion Germany (Berdahl 2010), in which she also analyses and interprets the film Goodbye, Lenin! (2003, d. Wolfgang Becker), and Svetlana Boym, who in the book The Future of Nostalgia (Boym 2001) focuses on the analysis and interpretation of nostalgia in the Soviet Union.

The phenomenon of ostalgia in the Czech Republic is also described in Czech academic literature from the area of film studies and other humanities by Martin Franz (2008), Blanka Činátlová (2011), Jan Černík (2016), Matouš Hájek, and Matěj Vlček (2011). For the foreign reader, historical context of the contemporary Czech film is closely analysed in the English-published book of Jan Čulík (2012).

\section{Nostalgia and Ostalgia}

According to Svetlana Boym (2011), the word "nostalgia" is based on two Greek linguistic roots:

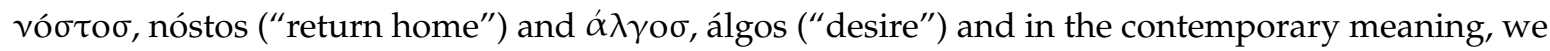
interpret it as a desire for a home that no longer exists or has never existed.

Boym furthermore differentiates between two basic types of nostalgia: Restorative nostalgia and reflective nostalgia. Restorative nostalgia focuses on the national past and future, reconstructing the tradition of the home and the nation to define time and space in a unified, objective manner. Because of this, it takes itself seriously (Boym 2001, p. 46).

On the other hand, reflective nostalgia focuses on the perception of history and passage of time through the individual and cultural memory. As such, it can be playful and ironic, combining personal experience with critical thinking, similarly to how memories mix emotion and compassion with logic and critical reflection. Reflective nostalgia is aware of the distance of the past, values the shattered nature of memory, and "has a capacity to awaken multiple planes of consciousness" (Boym 2001, p. 46).

Boym characterises nostalgic films as: "A cinematic image of nostalgia is a double exposure, or a superimposition of two images home and abroad, of past and present, of dream and everyday life. The moment we try to force it into a single image, it breaks the frame or burns the surface" (Boym 2011). I believe that these duplicities also appear in Czech ostalgic films.

The term ostalgia was created by combining the German words Nostalgie (nostalgia) and Ost (east) (Berdahl 2010, p. 48). It names the sentimental nostalgia for some aspects of the socialist lifestyle before the fall of the Iron Curtain in Central and Eastern Europe. This phenomenon first arose in the former German Democratic Republic, where the reunification of Germany caused social and political changes the fastest. Gradually, ostalgia also appeared in other countries. The German comedy Goodbye, Lenin! became the symbol of ostalgia with its absurd portrayal of a re-united Germany.

In the Czech Republic, ostalgia shows interest for art and pop culture from the normalisation period, and some specific products (often substitutes) from the time. For example, Kofola-a substitute of coca cola-successfully competes with the American original and is a part of the most sold Czech sweet drinks. At the turn of the millennium, the popularity of normalisation-pop stars rose. Czech television (public and private) repeat television shows and films from the normalisation period, including propaganda works like the series Thirty Cases of Major Zeman/Třicet prípadu majora Zemana (1974-1979, d. Jiři Sequens) about the history of Czech communist security (police), whose work was often based on fighting outer and inner ideological enemies. 


\section{The Tradition of Czech Nostalgic Film}

Nostalgia, as understood by Svetlana Boym (an escape from contemporary issues and a return into a world that is easy to comprehend even if it had never existed), has a tradition in Czech cinematography since the 1930s. After Hitler was elected in Germany, but before the unification of Germany and Austria, two films were created in a Czech-Austrian production, which portrayed an unproblematic cohabitation between Czechs and Germans in Czechoslovakia, despite the fact that Czech-German inhabited areas were riddled with significant tension due to nationalism. The melodrama The Sauvage from Egerland/V cizím reviru/Der Wilderer vom Egerland (1934, d. Vladimír Majer and Walter Kolm-Velteee) tells the story of a woods adjutant, a poacher, and two girls set in the area of western Czech spas, which is presented as nationally harmonic. In the film, there is no conflict between Czechs and Germans, only between the protagonists and antagonists. The central couple drives to Karlovy Vary (Carlsbad), which is presented as a lively and prosperous multi-cultural spa city.

Non-conflict multi-cultural relationships appear in the film Jana, the Girl from the Bohemian Forest/Jana/Jana, das Madchen aus Böhmerwald (1935, d. Robert Land and Emil Synek), which was shot simultaneously in two languages. The melodramatic film about love is set in an idyllic village in the Bohemian Forest near the borders. According to Alice Aronová, the two versions are different even though the film's plot remains the same, and the main difference is the interpretation of the village- the Czech village is replaced by a typically German one. Paradoxically, the Czech Jana was considered too Sudeten-German in the patriotically-obsessed time, while the German Jana is considered too Czech. However, the important part is the appearance of the two versions: The villagers appear proper and respectable to the spectator and they live comfortably, in harmony with the nature around them, in a place which honours Catholic faith, as well as traditional and moral values (Aronová 2013).

Both films make use of the idyllic chronotope, which Michail Bahktin describes in relation to the novel of the 19th century: "Life and its events is ideally organically linked to a place-the nation and all its corners, its mountains, valleys, fields, rivers and ice, a father's home. Idyllic life and its events are grown with a concrete place, where fathers and grandfathers used to live, where children and grandchildren can live. This small world, this limited and self-sufficient place is not particularly linked with other places, with other worlds" (Bakhtin 1982, p. 225). According to Bahktin, the chronotope characterises a specific organisation of time and space that is typical for the specific literary genre of the given period. The translator and interpreter of Bachtin, Michael Holquist, understands the chronotope as a device of synthetical analysis (Holquist 1982, p. xxxiii). According to Vivian Sobchack, one of the explored chronotopes in film is e.g., the chronotope of the film noir, which is the opposite of Bachtin's so-called idyllic chronotope (Sobchack 1998). I believe that the construction of time-space in Czech ostalgic films is similar to Bachtin's idyllic chronotope.

The bloom of Czech nostalgic films occurred during the Second World War, when Czech cinematography was controlled by German occupant authorities, but Czech films were shot in Czech production. For more detail, see Tereza Dvořáková (2011). Conversational comedies were greatly liked by audiences, which usually occurred in higher classes, and made use of stereotypes interpreted from the idyllic chronotope. These comedies were marked by being seemingly apolitical. There was nothing said of the war, there were no social disagreements, members of separate social classes still communicated and acted respectfully to one another. In the film Catacombs/Katakomby (1940, d. Martin Frič), a lower-set official of the Land Office, portrayed by the popular Czech comic Vlasta Burian, manages to become the general secretary of the office through his simple truthfulness and skill in the folk card game Mariás. The rude factory owner in the film Chalk and Cheese/Nebe a dudy (1941, d. Vladimír Slavínsky), who has amnesia after a car accident, is fixed by staying with the family of a quarry worker. Lukáš Kašpar writes about the ambivalence of these films in terms of nostalgic values and emphasises the phenomenon of hidden propaganda, which was related to escapism films: "Propaganda in a Czech acted film is a generally neglected phenomenon, similarly to the role of a film acting in the frame of Nazi propaganda. The escapism of Czech films is often noted in literature in relation to protective tendencies rather than a part of propaganda intentions" (Kašpar 2007, p. 17). A 
similar ambivalence was pointed out by criticism of Czech ostalgic films about normalisation, which is the main theme of this essay.

Specific nostalgic appearances were seen in some films of socialist construction from the 1950s, which showed how communism was becoming the reality of the everyday (nostalgia therefore does not come from an idealised past, but the wish for a utopic future). The musical film Tomorrow, People Will Be Dancing Everywhere/Zitra se bude tančit všude (1952, d. Vladimír Vlček) shows a young people's folk choir, which diligently trains in folk songs and dances, and as a reward, they participate in the International Festival for Youths in Berlin in 1951. The nostalgic atmosphere of a dancing and laughing company, which in reality was encompassed by communist terror, is portrayed even in the film's title.

Audience-popular (so far!) comedy Holiday with Angel/Dovolená s Andělem (1952, d. Bořivoj Zeman) introduces a non-communist inspector of a transport company in Prague who is on a holiday for disciplined workers organised by the Revolution Trade Union Movement. The holiday-goers are prohibited from work, but suffer from withdrawal symptoms of workaholism and end up reconstructing a local kindergarten. Angel, under the influence of the collective, turns into an entertaining individual with a heart of gold. The audience interest created a winter-based sequel, and Angel in the Mountains/Anděl na horách (1955, d. Bořivoj Zeman).

In the 1960s, especially in films following the generation of the New Wave, nostalgic films were sidelined. Nostalgic elements in the following generation appear only in films of Jiří Menzel and Jaromil Jireš. The artistic use of nostalgia is different from the suggested analysis and extends beyond the scope of this article.

The nostalgic atmosphere of the old Austria-Hungary appears in mystification comedies with absurd elements, such as Jára Cimrman Lying, Sleeping/Jára Cimrman ležící, spící (1983, d. Ladislav Smoljak), Dissolved and Effused/Rozpuštěný a vypuštěný (1984, d. Ladislav Smoljak), which transfer the character of a fictive unacknowledged genius and poly-historian from the Jára Cimrman's theatre of to the big screen. Austria-Hungary was, before its collapse in 1918, called "the jailer of nations" by Czechs. The ideologies of the first republic (1918-1938) and of communist Czechoslovakia (1948-1989) sharply defined against the "old monarchies". In an allegorical reading, which was not the author's primary focus, monarchy was presented full of comic paradoxes; however, it was also a place in which the eccentric dreamer can be at least partially fulfilled. Allegorical readings were focused against communistic unification and levelling. Cimrman in a specific way fought against Austria-Hungary when, as teacher to the children of the throne's successor, he taught his students the idea of monarchy's downfall. The film attempts to translate the specific poetic of the theatre based on an emphasised naïve acting performance, absurd character behaviour, and diction-based humour in the film.

Though the described films with elements of nostalgia from different time periods do encompass similar nostalgic motives (security, unreality, simplicity, naiveté), and use a transformed idyllic chronotope, they do not use a focalisation of a child's point of view: They are separate in their relation to the official nation's ideology and the source of nostalgia. The silence over national conflict between Czechs and Germans in films from the Sudetenland in the 1930s singularly supports the official politics of a single "Czechoslovakian" nation (they link back to an atmosphere of a close, still uncomplicated past). Nostalgic comedies that ignore the war from the Protectorate period have two ambivalent interpretations that relate to the contemporary war time. Firstly, they can be interpreted as having defence tendencies towards the Czech nation against occupation (a direct disagreement or resistance was not allowed to be portrayed in film) and secondly, as hidden German propaganda that shows a comfortable life in time of war, which is insured through Nazi Germany's defence system. Comedies of socialist construction from the 1950s openly worked as propaganda for communist ideologies: The source of nostalgia was presented through a utopic future, as films from the present showed how life will be when everyone will live according to the communist codex and class enemies will disappear. Closely Watched Trains using reflexive nostalgia mainly as an artistic contract is the least ideological; ideological reading of the film happened later, similarly to Austria-Hungarian mystification comedies from the 1980s. The films in the described period show a desire for a homogenous social state which is 
ruled by a social peace and a conservative interpretation of a family (typical for restorative nostalgia). As will be shown in the following section, these two motives strongly emphasise ostalgic films in the normalisation period, although the ideology of these films promotes liberal views which, according to results from elections and sociological researches, were only held by a small minority.

\section{Normalisation and Films about Normalisation}

The normalisation period (1969-1989) is marked by years following the suppression of the Prague Spring in 1968 by the Soviet army, when the leadership of the communist party was taken in 1969 by the later Czechoslovakian president Gustav Husák. According to the communist propaganda of the time, it was a return to the "normal" social conventions before the Prague Spring. Society was characterised by political lack of freedom, one-party government, discrimination of citizens who disagreed with the state, closed borders to the West, bad living conditions in industrial areas, and chronic lack of everyday goods and services, which connected to corruption and creation of paralleled economic structures. Most citizens did not identify with the regime, but were too scared to publicly speak their mind. Critique and ridicule of the regime only happened privately between friends and family.

Already in the overthrow in 1989, the time was viewed as years of stagnation and economic, social, and moral bankruptcy. Films about normalisation, which began to be filmed after 1989, took these judgements, but the actual social meaning focused on the contemporary reimaged structure of Czech society. Because of this, the epilogues of many films happen after November 1989. After the turn in 1989, society did not start to expand according to initial (clearly naïve) ideas of quickly achieving Western standards of living and economical stature. Economic and political corruption grew across the country, a clear social differentiation was caused, and a part of the society (namely the old and less educated citizens in rural areas) could not adjust to the sudden changes.

\subsection{Films about Normalisation}

Several films were shot about normalisation after 1989, which divide into dramas and comedies. Already in 1990 was shot the grotesque drama The Czech Song of Ours II/Ta naše pisnička česká II (1990, d. Vít Olmer) followed by two absurd comedies The Smoke/Kouř (1991, d. Tomáš Vorel) Let's All Sing Around/Pějme písen̆ dohola (1991, d. Ondřej Trojan); none of the three films caught the audience's attention. Dramas from normalisation marked a significantly smaller audience interest, but were upheld by Czech critics and gained Czech film awards. An extreme case was the minimalist art filmEighty Letters/Osmdesát dopisư (2011, d Václav Kadrnka) shot in independent production that was marked by some critics as a unique creation.

The first film with nostalgic memories of adolescence Thanks for Every New Morning/Diky za každé nové ráno (1994, d. Milan Šteindler) had its premiere in 1994. Several films followed, shot in an ostalgic way that offered sentimental views of the everyday in a communist state. They welcomed a significant audience interest, but the critics judged these films in a reserved manner. One of the criticisms was whether it is morally right to shoot nostalgic films about normalisation.

The breakthrough ostalgic film was Kolja (1996, d. Jan Svěrák) which earned an Oscar for the best foreign language film.

In the table below are shown the audience visits to cinemas; in television, the difference in viewership between dramas and ostalgic comedies was even greater (Table 1).

The emotions of nostalgia, by my judgement, are generated on three levels, which correspond with the narrative-cognitive approach of David Bordwell (1985). The first and second are joined with the structure of the art piece, while the third is about audience response:

1. Story, characters, setting;

2. Film style, narration, and genre;

3. Audience response (identification, causality of emotional experience). 
Table 1. Films about normalisation: Audience in cinemas (official data from Union distributors).

\begin{tabular}{ccccc}
\hline Film & Year of Filming & Director & Audience Numbers & Genre \\
\hline Kolja & 1996 & Jan Svěrák & $1,346,669$ & ostalgia \\
Pupendo & 2003 & Jan Hřebejk & 988,457 & ostalgia \\
Občanský pri̊kaz & 2010 & Ondřej Trojan & 428,688 & ostalgia \\
Báječná léta pod psa & 1997 & Petr Nikolaev & 344,865 & ostalgia \\
Něžné vlny & 2014 & Jiří Vejdělek & 246,659 & ostalgia \\
Probudím se včera & 2012 & Miroslav Šmídmajer & 241,252 & ostalgia \\
Diky za každé nové ráno & 1994 & Milan Šteindler & 207,241 & ostalgia \\
Kawasakiho rǔže & 2009 & Jan Hřebejk & 167,842 & drama \\
Fair Play & 2014 & Andrea Sedláčková & 86,043 & drama \\
Zemsḱ́ ráj to napohled & 2009 & Irena Pavlásková & 50,518 & drama \\
. a a bude hůř & 2008 & Petr Nikolajev & 33,294 & drama \\
Pouta & 2010 & Radim Špaček & 27,049 & drama \\
Don't Stop & 2012 & Richard Řeřicha & 5096 & drama \\
Osmdesát dopisů & 2011 & Václav Kadrnka & 1888 & drama \\
\hline
\end{tabular}

\subsection{Story, Characters, Setting}

Ostalgic films often begin with the occupation of the Soviet army (the said reason for normalisation). The main story occurs between 1968 and 1989. The epilogue usually shows the fall of the Iron Curtain and the Velvet revolution. In the film Goodbye, Lenin!, events ahead of the fall of the Berlin Wall create the prologue of the main plot, which occurs during the re-unification of Germany. Ostalgia is portrayed directly, not as a historical allegory as is done in Czech ostalgic films. In the German film, fundamental problems appear for the protagonists as a result of the fall of the Berlin Wall. On the other hand, problems of Czech protagonists are solved, partially showing unfulfilled expectations after 1989. Films ignore "the greater history" and focus on everyday life, the centre of which is the middle-class family. Representatives of the regime are often mocked and parodied, often appearing as dumb and clumsy good guys. On the other hand, in dramas, they gain demonic characteristics. High party members and state officials do not appear in the analysed films.

In the film Goodbye, Lenin!, all of the citizens face issues of the new age; for example, a past prominent member of the communist regime-the first East Germany astronaut-works as a taxi driver. In the Czech films Tender Waves/Něžné vlny (2014, d. Jiří Vejdělek) and Those Wonderful Years that Sucked/Báječná léta pod psa (1997, d. Petr Nikolaev), which portray the fates of people after 1989, prominent communists are the first to adjust to the new social conditions. A divide of society remains between $u s$ (ordinary citizens) and them (those that adjust to every regime).

Most protagonists are from a middle class (their parents have college educations, they are intellectuals, children study or the state has prevented them from doing so). The regime tries to suppress the typical portrayals of the middle class (doctors, teachers, scientists, intellectuals) by weakening their social authority and a smaller financial value of their work. The view of manual and rural jobs, which was common in normalisation films, is usually missing in ostalgic films.

Most ostalgic films (but also dramas!) portray the family as one of the ground personal and social values. Generational misunderstandings are shallow and arise from a need to emancipate the adolescent, which the parent generation understands. Pressure created by the regime on one of the family members lets them overcome marital or generational family crises and the whole family unites. The regime limits the classical patriarchal function of the father as an authority. The role of the family authority is taken by the mother, who usually has a sense for the pragmatic function of the household and has no interest in the political.

Protagonists of Czech ostalgic films do sacrifice their personal comfort for the benefit of the family, like in the film Goodbye, Lenin!, but they do not deal with personal issues in an active manner. It is as if they await for the problems to fix on their own, such as in the aforementioned Czech films from the occupation period. The active effort in searching for the protagonist of the German films concludes in a painful confrontation with the father, and the protagonist must reconsider his past actions. 
A sense of nationalism is missing; the idea of Czech is viewed as natural and unproblematic. While characters negatively act towards Russians (Identity Card/Občanský pri̊kaz (2010, d. Ondřej Trojan), An Earthly Paradise for the Eyes/Zemský ráj to napohled (2009, d. Irena Pavlásková), Tender Waves/Něžné vlny (2014, d. Jiří Vejdělek)), it is not because of their nationality, but because of their status as occupants. Russian culture and aesthetic demands respect. No film shows, even on a symptomatic level, discrimination against national minorities (in most of Czech society, the Roma are unpopular). Nationalistic feats are replaced by a disinterest in other nations. Czech isolationism is portrayed by the inability to communicate in foreign languages. The Russian language is taught in schools by incompetent teachers (Pupendo, Identity Card, Tender Waves). Most citizens do not know Western languages; the English skills of characters in Pupendo (2003, d. Jan Hřebejk) appear comic. In the film Goodbye, Lenin!, opposing opinions and the lifestyle of East and West Berliners are confronted in a comedic manner. This confrontation leads to a reflection of the re-unification of Germany, the ideals on which it should be built, and the manner with which it should approach the citizens of the Eastern part of the country.

Films about the life of emigrants are missing; most of the Czech society views them with suspicion.

In the analysed films, there is almost no portrayal of any religion, which corresponds with the Czech society being dominantly atheist.

None of the nostalgic films or television series advocate the regime as a whole or attempt to find something positive (free health service, full employment, available pre-schools and nurseries).

\subsection{Style, Narrative, Genre}

This level is largely fad- and convention-based, showing some characteristics of kitsch (likeability, sentiment, emphasis of easy identification and no conflict). In the majority, it is about comedy with a happy ending. Only the film Identity Card has elements of tragedy, as one of the four friends dies as he tries to avoid compulsory army conscription. On the other hand, the drama about the life of dissidents An Earthly Paradise for the Eyes (an ironic quote from the Czech anthem) has comedic elements. The film style has an organised staging, the camera work and cut mainly unmarked and conventional. Only Kolja uses a brighter style inspired by Hollywood staging, mainly the style of Steven Spielberg, but even so, it is second to the need of the narrative. The film Those Wonderful Years that Sucked/Báječná léta pod psa has a marked style differentiated by a writer's vision of a beginning author. Warm colours dominate the film and the narrative usually occurs in spring and summer months in the countryside or small towns.

Films are narrated linearly; usually, there is no subjective viewpoint of storytelling. Only in Kolja is a subjective point of view utilised, through the eyes of a small boy experiencing high fever. Films are told from the focalised viewpoint of a child or adolescent hero. The selective manner of memories is explained by the naïve experience of a child, with which can nostalgically identify the grown spectator. This focalisation of the story greatly helps the simplified interpretation of history. On the one side there is Us (the family), on the other side is Them (the regime). Ostalgic films refuse to cast blame on individuals for the existence of the regime.

The humour in Czech ostalgic films is usually kind and unproblematic, similar to the humour of Protectorate comedies. Most of the jokes are not a reaction on the social situation, but use universal tropes of situational humour. The humour is not based on the embarrassment of everyday situations like Miloš Forman's comedies from the New Wave period in film, neither does it resemble the offensive social satire like Verra Chytilová's comedies. The humour in Goodbye, Lenin! comes mainly from the confrontation between protagonists from East and West parts of Berlin.

\subsection{Audience Response and Sociological Research}

Audience response to ostalgic films is not homogenous. Ostalgic films bring sentimental emotion, but simultaneously reject the past regime. However, this stance does not correspond with sociological research of society from the last few years, which was done by the Institute of Sociology, Academy 
of Sciences of the Czech Republic (press release from February 2018) that summarises the opinions of the Czech public on a democratic level and the respecting of human rights in the Czech Republic. The opinion that conditions now are better than before 1989 is backed by $38 \%$ of the population. The opinion that conditions were better before 1989 is backed by $17 \%$. The older generation (more than 45 years) judges pre- 1989 conditions more favourably than the younger generation.

Two thirds (66\%) of the Czech public are persuaded that the change of the social system in 1989 was worth it.

Liberal democracy as the best way of governance is preferred by $60 \%$ of the public, while the rest of the population calls for non-liberal state governance, with a strong leader as the head of the state (it is mostly voters from the countryside with lower education) (Centre for Research of Public Opinion 2018). I believe that this social group does not visit the cinema, but they watch private-run television that repeats normalisation films and series; they do not trust classical news mediums and fall for hybrid propaganda.

Reception of ostalgic films can be interpreted in different social groups through different reasons:

1. Nostalgia for childhood: A positive emotional response is created through similarity with personal memory, often from the childhood and adolescent periods, linked with the discovery of own identity.

2. Symbolic ritual of parting: Part of the audience views ostalgic films as a symbolic ritual of parting (with youth, the past, a singularly defined ideological enemy) as described by German sociologist Daphne Berdahl while analysing the film Goodbye, Lenin!

3. Intelligibility and feeling of safety: Thanks to a simple style and narration, the films are intelligible for older generation spectators, who live in fear of the future, because they stop understanding the present in values and taste.

4. Absurd backdrop: The younger audience, who have no experience with the past regime, understand normalisation as a strange and comic period that explains why they do not relate to their parents and grandparents, who had lived a big portion of their lives during normalisation.

\section{Conclusions-The Paradox of Ostalgic Films}

From the initial questions based on Rosenstone, there arises a basic theme from the completed analysis that unquestionably relates to the representation of history in the contemporary.

Czech ostalgic films present a unified representation of history. They arise straight from a tradition of Czech nostalgic film. All of the films are characterized by a classic non-incidental style, simple narration, and the comedic genre. All of the films are also connected through similar themes: Difficulty of everyday life during socialism, difficulty of adolescence, discovery of self-identity. All of the films place a clear focus on the irreplaceable function of the family. The resulting construction of the historical time-space creates the analogy of an idyllic chronotope, as described by Bakhtin. This simple and ostensibly unproblematic representation hides a fundamental paradox of Czech ostalgic films. It is clear that there arises a paradox between a refusal of the ideological regime and a non-conflict nostalgic view on the era, where the Czech society was in a deep political, economic, and moral bankruptcy. The liking of these films does not portray an agreement with the ideology of the past regime, or even a wish for its return, but rather strictly refuses it. Films rather offer a momentary escape from the future, which most of the public views with worry. Furthermore, it allows spectators to get rid of personal responsibility, as well as moral and existential guilt. Due to singular anti-communist viewpoints and emphasised liberal values, the films cannot be interpreted in a desire for an idealised home in a communist past, but as a desire for a present home and its security, which cannot be clearly conceptualised.

The answer to the second Rosenstone question is linked with the character and function of ostalgia. Czech ostalgic films about the normalisation period have a double exposure, as described by Boym, and are interpretively ambivalent. They cannot be simply classified into restorative or reflective nostalgia. They pretend that they create individual and cultural memory (typical for reflective nostalgia) while they rather create a unified national memory typical for restorative nostalgia. The younger generation 
of spectators perceive ostalgic films in the mode of reflective nostalgia; on the other hand, the older generation perceive the films in terms of restorative nostalgia. This differing generational perception of ostalgia refers to a distinct split in Czech society based on the different generational experiences.

The concept of reflective nostalgia can be linked with the theory of Berdhal, who interprets ostalgic films as a ritual farewell with the communist past. I believe that the contradictions between reflective nostalgia and restorative nostalgia arise from a specific status of the post-communist period which is portrayed through an opinion-based confusion of the society's majority.

The answer to the third question "How do historical films present current issues" is given by Croatian philosopher Boris Buden, when he describes the deep contradictions of post-communist societies in Eastern Europe. The term post-communism (first used by Zbigniew Brzeziński) (Buden 2013, p. 23) became true for the unfinished time of political, economic, and cultural transformation in the countries of the former Eastern bloc, which began after the fall of the Iron Curtain in 1989. In parallel, the term post-socialism is used, as for example by aforementioned Berdahl.

The effects of the past regime in the present feature as much deeper and the transition period is much longer than had been originally estimated. Buden compares the state of countries in Central and Eastern Europe to the zone from Andrei Tarkovsky's film Stalker (1979). "Travelling the land does not lead anyone from the grim industrial countryside with collapsing industry objects, caught in melancholy sepia greys, into a place buried in bright light and pastel tones. Everything is beautiful, vivid, birds sing, the grass grows green ... in this zone all wishes will be fulfilled" (Buden 2013, p. 11). However, the wishes are not fulfilled and the travellers return into the grey reality. According to Buden, the allegorical level of the film does not show the transition from dark reality of real socialism to the bright world of democracy and trade prosperity (and subsequent disappointment). It shows a much graver historical moment-the fall of industrial modernism, which was equal for both conquering worlds even before 1989 .

I believe that ostalgic films not only portray negative reactions-disappointment from the present and worry concerning the future as formulated by Buden - but also portray the positive (if perhaps naïvely) as they formulate the fundamental desire and needs of citizens from present Czech society, and even encourage spectators to create "new social contracts" with the current regime. On the sidelines, there remains the self-realisation in work and social security. The key requirements become a life in a harmonic family, generational understanding, and a sense of pride. Not to be a joke, as it had been in the period of normalisation.

Funding: This research was funded by Faculty of Arts, Palacky University Olomouc, grant number: FPVC 2015/13.

Conflicts of Interest: The funders had no role in the design of the study; in the collection, analyses, or interpretation of data; in the writing of the manuscript, or in the decision to publish the results.

\section{References}

An Earthly Paradise for the Eyes/Zemský ráj to napohled, 2009. Directed by Irena Pavlásková. Praha: Cineart TV Prague.

Angel in the Mountains/Anděl na horách, 1955. Directed by Bořivoj Zeman. Praha: Czechoslovak State Film.

Aronová, Alice. 2013. Jana. In Dvojitá hranice-Československý vícejazyčný film. Available online: http:/ / www. goethe.de/ins/cz/prj/gre/flm/dop/cs10334650.htm (accessed on 24 August 2018).

Bakhtin, Mikhail M. 1982. The Dialogic Imagination: Four Essays. Translated by Caryl Emerson, and Michael Holquist. Austin: University Texas Press.

Berdahl, Daphne. 2010. On the Social Life of Post-socialism Memory, Consumption, Germany. Bloomington and Indianopolis: Indiana University Press.

Bordwell, David. 1985. Narration in the Fiction Film. Madison: The University of Wiskonsin Press.

Boym, Svetlana. 2001. The Future of Nostalgia. New York: Basic Books.

Boym, Svetlana. 2011. Nostalgia. In Atlas of Transformation. Available online: http:/ / monumenttotransformation.org/ atlas-of-transformation/html/n/nostalgia/nostalgia-svetlana-boym.html (accessed on 24 August 2018). 
Buden, Boris. 2013. Konec postkomunismu Od společnosti bez naděje k naději bez společnosti. Translated by Radovan Baroš. Praha: Rybka Publishers.

Catacombs/Katakomby, 1940. Directed by Martin Frič. Babelsberg: UFa.

Centre for Research of Public Opinion. 2018. Press Release of Belief of Czech Public on a Democratic Level and the Respecting of Human Rights/Tisková zpráva Názory české veřejnosti na úroveň demokracie a respektování lidských práv v ČR. Sociologický ústav AV ČR. February. Available online: https://cvvm.soc.cas.cz/media/ com_form2content/documents/c2/a4553/f9/pd180316.pdf (accessed on 24 August 2018).

Černík, Jan. 2016. Ostalgická nálada v českém historickém filmu po roce 1989. In Film a dějiny 6 . Edited by Luboš Ptáček and Petr Kopal. Praha: Casablanca, pp. 30-43.

Chalk and Cheese/Nebe a dudy, 1941. Directed by Vladimír Slavínsky. Praha: Lucernafilm.

Činátlová, Blanka. 2011. Zátiší se sifonovou lahví Fotogenie ostalgického vzpomínání. Cinepur 78: 65-75.

Čulík, Jan. 2012. A Society in Distress: The Image of the Czech Republic in Contemporary Czech Feature. Brighton: Sussex Academic Press. Brighton: Sussex Academic Press.

Dissolved and Effused/Rozpuštěný a vypuštěný, 1984. Directed by Ladislav Smoljak. Praha: Czechoslovak Film.

Dvořáková, Tereza. 2011. Idea filmové komory Českomoravské filmové ústředí a kontinuita centralizačních tendencí ve filmovém oboru 30. a 40. let. Ph.D. dissertation, Univerzita Karlova, Praha, the Czech Republic, June 27. Available online: https:/ / is.cuni.cz/webapps/zzp/detail/25027 (accessed on 24 August 2018).

Eighty Letters/Osmdesát dopisů, 2011. Directed by Václav Kadrnka. Praha: Bystrouska, Marietta: Cinepost.

Franz, Martin. 2008. Ostalgie v Čechách. In Kapitoly z dějin české demokracie po roce 1989. Edited by Adéla Gjuričová and Michal Kopeček. Praha: PASEKA, pp. 193-216.

Goodbye, Lenin! 2003. Directed by Wolfgang Becker. Berlin: X-Filme Creative Pool.

Hájek, Matouš, and Matěj Vlček. 2011. Špatná pamět' a bohaté vzpomínky. Cinepur 76: 70-73.

Holiday with Angel/Dovolená s Andělem, 1952. Directed by Bořivoj Zeman. Praha: Czechoslovak State Film.

Holquist, Michael. 1982. Introduction. In Bakhtin, Mikhail M. The Dialogic Imagination: Four Essays. Translated by Caryl Emerson, and Michael Holquist. Austin: University Texas Press, pp. xv-xxxiv.

Identity Card/Občanský průkaz, 2010. Directed by Ondřej Trojan. Praha: Total HelpArt.

Jana, the Girl from the Bohemian Forest/Jana/Jana, das Madchen aus Böhmerwald, 1935. Directed by Robert Land and Emil Synek. Praha: Meissner Film Prague.

Jára Cimrman Lying, Sleeping/Jára Cimrman ležící, spící, 1983. Directed by Ladislav Smoljak. Praha: Czechoslovak Film.

Kašpar, Lukáš. 2007. Český hraný film a filmaři za protektorátu. Propaganda Kolaborace Rezistence. Praha: Libri. Kolja, 1996. Directed by Jan Svěrák. Praha: Biograf.

Let's All Sing Around/Pějme píseň dohola, 1991. Directed by Ondřej Trojan. Praha: Filmové studio Barrandov.

Ptáček, Luboš. 2018. Mezi alegorií a ideologií. Proměna reprezentace historie v českém historickém filmu a televizním seriálu. Praha: Casablanca.

Pupendo, 2003. Directed by Jan Hřebejk. Praha: Total HelpArt.

Rosenstone, Robert A. 1995. Visions of the Past: The Challenge of Film to Our Idea of History. Boston: Harvard University Press.

Rosenstone, Robert. A. 2012. History on Film/Film on History. London and New York: Routledge.

Sobchack, Vivien. 1998. A lounge time: postwar crisis and chronotope of film noir. In Refiguring American Film Genres. Edited by Nick Browne. Berkeley and Los Angeles: University of California Press, pp. 129-71.

Stalker, 1979. Directed by Andrei Tarkovsky. Moscow: Mosfilm.

Thanks for Every New Morning/Diky za každé nové ráno, 1994. Directed by Milan Šteindler. Praha: KF, Česká televize, Česká filmová společnost.

Tender Waves/Něžné vlny, 2014. Directed by Jiří Vejdělek. Praha: Infinity Prague.

The Sauvage from Egerland/Der Wilderer vom Egerland/V cizím revíru, 1934. Directed by Walter Kolm-Veltée and Vladimír Majer. Berlin: Terra.

The Smoke/Kouř, 1991. Directed by Tomáš Vorel. Praha: Filmové studio Barrandov.

The Czech Song of Ours II/Ta naše písnička česká II, 1990. Directed by Vít Olmer. Praha: Filmové studio Barrandov.

Thirty Cases of Major Zeman/Třicet prípadi̊ majora Zemana, 1974-1979. Directed by Jiří Sequens. Praha: Czechoslovak Television. 
Those Wonderful Years that Sucked/Báječná léta pod psa, 1997. Directed by Petr Nikolaev. Praha: ČT Praha, Space films. Tomorrow, People Will Be Dancing Everywhere/Zitra se bude tančit všude, 1952. Directed by Vladimír Vlček. Praha: Czechoslovak State Film. article distributed under the terms and conditions of the Creative Commons Attribution (CC BY) license (http://creativecommons.org/licenses/by/4.0/). 